\title{
Robust antibody levels in both diabetic and non-diabetic individuals after BNT162b2 mRNA COVID-19 vaccination
}

Hamad Ali ${ }^{1,2 \#}$, Abdelmohsen AlTerki ${ }^{3,4 \#}$, Sardar Sindhu ${ }^{5,6 \#}$, Barrak Alahmad ${ }^{7}$, Maha Hammad $^{8}$, Salman Al-Sabah ${ }^{9}$, Mohammad Alghounaim ${ }^{9}$, Mohammad H. Jamal ${ }^{9}$, Ali Aldei ${ }^{10}$, Mohammad J. Mairza $^{11}$, Maitham Husain ${ }^{12}$, Sriraman Deverajan ${ }^{13}$, Rasheed Ahmad ${ }^{5}$, Preethi Cherian ${ }^{8}$, Irina Alkhairi $^{8}$, Abdullah Alkandari ${ }^{2}$, Jehad Abubaker ${ }^{*^{*}}$, Mohamed Abu-Farha ${ }^{8 *}$, Fahd Al-Mulla ${ }^{2 *}$

1. Department of Medical Laboratory Sciences, Faculty of Allied Health Sciences, Health Sciences Center (HSC), Kuwait University, Jabriya, Kuwait

2. Department of Genetics and Bioinformatics, Dasman Diabetes Institute (DDI), Dasman, Kuwait

3. Department of Otolaryngology, Head, and Neck Surgery, Zain and Al-Sabah Hospitals, Ministry of Health, Kuwait City, Kuwait

4. Medical Division, Dasman Diabetes Institute (DDI), Dasman, Kuwait

5. Department of Immunology and Microbiology, Dasman Diabetes Institute (DDI), Dasman, Kuwait

6. Animal \& Imaging Core Facility, Dasman Diabetes Institute (DDI), Dasman, Kuwait

7. Department of Environmental Health, Harvard T.H. Chan School of Public Health, Harvard University, Boston, MA, United States of America

8. Department of Biochemistry and Molecular Biology, Dasman Diabetes Institute (DDI), Dasman, Kuwait

9. COVID-19 Research Group, Jaber Al-Ahmad Al-Sabah Hospital, Kuwait City, Kuwait

10. Rheumatology unit, Department of Medicine, Amiri Hospital, Kuwait City, Kuwait

11. Department of Internal Medicine, Amiri Hospital, Kuwait City, Kuwait

12. Planning and follow up department, Ministry of Health, Kuwait City, Kuwait

13. National Dasman Diabetes Biobank, Dasman Diabetes Institute (DDI), Dasman, Kuwait

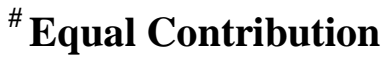

\section{* Corresponding Authors}

jehad.abubakr@dasmaninstitute.org, fahd.almulla@dasmaninstitute.org and mohamed.abufarha@dasmaninstitute.org

Keywords: COVID-19, SARS-CoV-2, type 2 diabetes, BNT162b2, mRNA vaccine, antibodies, humoral response 
medRxiv preprint doi: https://doi.org/10.1101/2021.07.23.21261042; this version posted August 8, 2021. The copyright holder for this preprint (which was not certified by peer review) is the author/funder, who has granted medRxiv a license to display the preprint in perpetuity.

It is made available under a CC-BY-ND 4.0 International license .

36 Hamad Ali ${ }^{1,2 \#}$, hamad.ali@hsc.edu.kw

37 Abdelmohsen Al-Terki, ${ }^{3,4 \#}$, abdulmohsen.alterki@dasmaninstitute.org

38 Sardar Sindhu ${ }^{5,6 \#}$, Sardar.Sindhu@dasmaninstitute.org

39 Barrak Alahmad ${ }^{7}$, b.alahmad@g.harvard.edu

40 Maha Hammad ${ }^{8}$, maha.hammad@ dasmaninstitute.org

41 Salman Al-Sabah ${ }^{9}$, salman.k.alsabah@gmail.com

42 Mohammad Alghounaim ${ }^{9}$, malghounaim@moh.gov.kw

43 Mohammad H. Jamal ${ }^{9}$, mjamal110@gmail.com

$44 \quad$ Ali Aldei ${ }^{10}$, Aldei2005@yahoo.com

45 Mohammad J. Mairza ${ }^{11}$, mairza.m@hotmail.com

46 Maitham Husain ${ }^{12}$, maitham_hussain@ @otmail.com

47 Sriraman Deverajan ${ }^{13}$, sriraman.devarajan@dasmaninstitute.org

48 Rasheed Ahmad ${ }^{5}$, rasheed.ahmad@dasmaninstitute.org

49 Preethi Cherian ${ }^{8}$, preethi.cherian@dasmaninstitute.org

50 Irina Alkhairi ${ }^{8}$, irina.alkhairi@dasmaninstitute.org

51 Abdullah Alkandari ${ }^{2}$, abdullah.alkandari@dasmaninstitute.org

52 Jehad Abubaker ${ }^{*^{*}}$, jehad.abubakr@dasmaninstitute.org

53 Mohamed Abu-Farha ${ }^{8}$, mohamed.abufarha@dasmaninstitute.org

54 Fahd Al-Mulla ${ }^{2 *}$, fahd.almulla@ dasmaninstitute.org

55

56

57

58

59

60

61

62

63

64

65

66

67

68 
medRxiv preprint doi: https://doi.org/10.1101/2021.07.23.21261042; this version posted August 8, 2021. The copyright holder for this preprint (which was not certified by peer review) is the author/funder, who has granted medRxiv a license to display the preprint in perpetuity.

It is made available under a CC-BY-ND 4.0 International license .

70 Abstract

71 The emergence of effective vaccines for COVID-19 has been welcomed by the world with great 72 optimism. Given their increased susceptibility to COVID-19, the question arises whether individuals 73 with type-2 diabetes mellitus (T2DM) and other metabolic conditions can respond effectively to the 74 mRNA-based vaccine. We aimed to evaluate the levels of anti-SARS-CoV-2 IgG and neutralizing 75 antibodies in people with T2DM and/or other metabolic risk factors (hypertension and obesity) 76 compared to those without. This study included 262 people that took two doses of BNT162b2 77 (Pfizer-BioNTech) mRNA vaccine. Both T2DM and non-diabetic individuals had a robust response 78 to vaccination as demonstrated by their high antibody titers. However, both SARS-CoV-2 IgG and 79 neutralizing antibodies titers were lower in people with T2DM. Their levels were $154 \pm 49.1$ vs.

$80138 \pm 59.4 \mathrm{BAU} / \mathrm{mL}$ for $\mathrm{IgG}$ and $87.1 \pm 11.6 \mathrm{vs} .79 .7 \pm 19.5 \%$ for neutralizing antibodies in individuals

81 without diabetes compared to those with T2DM, respectively. In a multiple linear regression adjusted 82 for individual characteristics, comorbidities, previous COVID-19 infection and duration since second 83 vaccine dose, diabetics had 13.86 BAU/ml (95\%CI: -27.08 to $-0.64 \mathrm{BAU} / \mathrm{ml}, \mathrm{p}=0.041)$ less $\mathrm{IgG}$ 84 antibodies and $4.42 \%(95 \% \mathrm{CI}$ : -8.53 to $-0.32 \%, \mathrm{p}=0.036)$ less neutralizing antibodies than non85 diabetics. Hypertension and obesity did not show significant changes in antibody titers. Taken 86 together, both type-2 diabetic and non-diabetic individuals elicited strong immune responses to

87 SARS-CoV-2 BNT162b2 mRNA vaccine; nonetheless, lower levels were seen in people with 88 diabetes. Continuous monitoring of the antibody levels might be a good indicator to guide 89 personalized needs for further booster shots to maintain adaptive immunity. 
medRxiv preprint doi: https://doi.org/10.1101/2021.07.23.21261042; this version posted August 8, 2021. The copyright holder for this preprint (which was not certified by peer review) is the author/funder, who has granted medRxiv a license to display the preprint in perpetuity.

It is made available under a CC-BY-ND 4.0 International license.

\section{Introduction}

91 COVID-19 pandemic has affected people worldwide to unprecedented proportions, even more 92 severely affecting the people with type-2 diabetes mellitus (T2DM) and/or those with other risk 93 factors for developing COVID-19 related complications. To date, more than 190 million people worldwide have been diagnosed with COVID-19, with an overall prevalence rate of at least $2 \%$ [1]. Although, mortality rates are generally lower (2.2\%), the presence of preexisting health conditions such as T2DM, hypertension, cardiovascular disease, and metabolic syndrome may contribute to increased case fatality rates up to $10 \%[2 ; 3 ; 4]$. A myriad of factors may contribute to increased susceptibility of T2DM patients for developing COVID-19 complications, including impaired innate/adaptive immunity, after the onset of a state of chronic, low-grade inflammation called metabolic inflammation. As a result, upon antigen exposure, the obesity-related chronic inflammation may impair macrophage activation and blunt the mechanisms of pro-inflammatory and/or innate cytokine production $[5 ; 6]$. This altered, obesogenic milieu may partly explain the presence of antiviral-resistance and vaccine escape mechanisms in obese and/or T2DM populations. Moreover, B and $\mathrm{T}$ cell responses are compromised in obese and more so in obese T2DM people [7]. The unfavorable hormone environment also primes for immune response dysregulation [8]. Typically, obese T2DM people may have defective innate/adaptive immunity, resulting from the enhanced production of several pro-inflammatory cytokines/chemokines like TNF- $\alpha$, IFN- $\gamma$, IL-1 $\beta$, IL-12, IL18, RANTES, MCP-1 and IL-6 [9]. Indeed, all these bioactive inflammatory proteins are also the factors that have been associated with an increased susceptibility for developing COVID-19 complications $[10 ; 11]$.

111 Driven by sheer urgency, COVID-19 vaccines have been developed at a phenomenal speed. One of 112 the most-widely used vaccines is known as BNT162b2 (Pfizer-BioNTech) which is an mRNA-based 113 COVID-19 vaccine that comprises of the nucleoside-modified mRNA (modRNA sequence of 4,284 114 nucleotides) encoding a mutated form (bases 103-3879) of the full-length spike (S) protein 115 (peplomer) of SARS-CoV-2 stabilized in its prefusion conformation as an antigen or immunogenic 116 molecule encapsulated in lipid nanoparticles that act as adjuvants [12]. The vaccine is administered 117 as two shots, intramuscularly, given three weeks apart and has been shown to offer protection by 118 triggering an immune response against infection by the SARS-CoV-2 spike protein. Since 119 BNT162b2 vaccine delivers mRNA encoding only for SARS-CoV-2 spike protein, the expected 
medRxiv preprint doi: https://doi.org/10.1101/2021.07.23.21261042; this version posted August 8, 2021. The copyright holder for this preprint (which was not certified by peer review) is the author/funder, who has granted medRxiv a license to display the preprint in perpetuity.

It is made available under a CC-BY-ND 4.0 International license.

120 elicited response is production of anti-S-RBD immunoglobulin G (IgG), IgM, and $\operatorname{IgA}$ isotypes, with

121 neutralization potential of inhibiting the RBD binding to ACE2 cognate receptor [13].

122 This study aimed to evaluate the humoral immune responses in people with and without T2DM 123 and/or other metabolic risk factors, such as hypertension and obesity. Herein, we present data 124 showing levels of SARS-COV-2-specific IgG as well as anti-S-RBD neutralizing antibodies in a 125 population with a high T2DM prevalence.

\section{Methods}

\subsection{Recruitment of Participants and Study Cohort}

128 This study was reviewed and approved by the Ethical Review Committee of Dasman Diabetes 129 Institute "Protocol \# RA HM-2021-008" as per the updated guidelines of the Declaration of Helsinki 130 (64th WMA General Assembly, Fortaleza, Brazil, October 2013) and of the US Federal Policy for 131 the Protection of Human Subjects. The study was also approved by the Kuwait Ministry of Health 132 ethical committee (reference: 3799, protocol number 1729/2021). This study aimed at recruiting 133 people that passed three weeks after taking the second dose of BNT162b2 (Pfizer-BioNTech) mRNA 134 vaccine. People with autoimmune diseases, those taking immunosuppressants or suffering from 135 arthritis were excluded from participating in this study as well as people with Type 1 Diabetes and 136 pregnant women. T2DM diagnosis was based on self-reporting. Data for each participant were 137 captured using a RedCap survey that included age, gender, existing diseases (e.g. diabetes and 138 hypertension) as well as height, weight, and history of COVID-19 infection. Obesity was defined 139 according to body mass index (BMI); those with $\mathrm{BMI}<25 \mathrm{~kg} / \mathrm{m}^{2}$ were considered normal weight,

140 with BMI between $25-30 \mathrm{~kg} / \mathrm{m}^{2}$ considered overweight and those with BMI > $30 \mathrm{~kg} / \mathrm{m}^{2}$ were 141 considered obese. Participants were then asked to visit the Dasman Diabetes Institute where they 142 signed up the informed consent form before participating in the study.

\section{$143 \quad 2.2$ Blood Sample Collection and Processing}

144 After signing the consent form, a venous blood sample was collected in Vacutainer EDTA tubes. The 145 blood was then centrifuged at $400 \times \mathrm{g}$ for $10 \mathrm{~min}$ at room temperature to isolate plasma. Plasma 146 samples were then aliquoted and stored at $-80^{\circ} \mathrm{C}$ until the assays were performed.

\section{$147 \quad 2.3$ Measurement of Plasma Levels of SARS-CoV-2-specific IgG}


medRxiv preprint doi: https://doi.org/10.1101/2021.07.23.21261042; this version posted August 8, 2021. The copyright holder for this preprint (which was not certified by peer review) is the author/funder, who has granted medRxiv a license to display the preprint in perpetuity.

It is made available under a CC-BY-ND 4.0 International license.

148 Plasma levels of SARS-CoV-2-specific IgG antibodies were detected using enzyme-linked 149 immunosorbent assay (ELISA) kit (SERION ELISA agile SARS-CoV-2 IgG SERION Diagnostics,

150 Würzburg, Germany), following the manufacturer's instructions. Briefly, plasma samples were 151 thawed at room temperature and centrifuged for $5 \mathrm{~min}$ at $10,000 \times \mathrm{g}$ at $4^{\circ} \mathrm{C}$ for sample clarification 152 and removal of residual cells or platelets. For assay, samples were diluted 100× using sample diluent

153 provided with the kit. Then, $100 \mu \mathrm{L}$ of controls, serum cutoffs (provided in the kit) and samples were 154 transferred into the designated wells and incubated for $60 \mathrm{~min}$ at $37^{\circ} \mathrm{C}$ in a humid chamber. 155 Following incubation, plates were washed $4 \times$ with $1 \times$ wash buffer and $100 \mu \mathrm{L}$ of antibody-specific 156 enzyme conjugate was added into each well. The plate was then incubated for $30 \mathrm{~min}$ at $37^{\circ} \mathrm{C}$ in 157 humid chamber and later washed $4 \times$ as before. Next, the chromogenic substrate (TMB solution) was 158 added into each well and incubated for $30 \mathrm{~min}$ at $37^{\circ} \mathrm{C}$ under humidity. Finally, the reaction was

159 stopped using the stop solution provided with the kit and the absorbance was read (Synergy H5 plate 160 reader) to measure optical density (O.D.) at $405 \mathrm{~nm}$ wavelength. The test evaluation was performed 161 following the positive and negative cutoffs as recommended by the manufacturer and IgG levels were 162 reported as binding antibody units $(\mathrm{BAU}) / \mathrm{mL}$. In this regard, IgG levels of $<21 \mathrm{BAU} / \mathrm{mL}$ were 163 considered negative, level of 21.0-31.5 BAU/mL were taken as border line and levels higher than 31.5 BAU/mL were considered as positive.

\subsection{Measurement of Plasma Levels of SARS-Cov-2-specific Neutralizing Antibody}

166 SARS-CoV-2-specific surrogate Virus Neutralization Test (sVNT) was used to detect levels of 167 plasma neutralizing antibodies against SARS-CoV-2 S-RBD (SARS-Cov-2 sVNT kit, GenScript, 168 USA, Inc). For sVNT assay, briefly, clarified plasma samples and kit controls were diluted 1:1 with $1691 \times$ horseradish peroxidase (HRP)-conjugated recombinant SARS-CoV-2 receptor binding domain 170 (HRP-RBD), as per the manufacturer's instructions. Diluted samples and controls were incubated at $17137^{\circ} \mathrm{C}$ for $30 \mathrm{~min}$ and later, the samples and controls, $100 \mu \mathrm{L}$ each, were transferred into designated 172 wells in the plate and incubated for $15 \mathrm{~min}$ at $37^{\circ} \mathrm{C}$. After incubation, wells were washed $4 \times$ with $1 \times$ 173 wash buffer and then recommended volume of TMB solution was added into each well and again 174 incubated for $15 \mathrm{~min}$ at $37^{\circ} \mathrm{C}$. Finally, stop solution was added to each well and the O.D. was 175 measured at $450 \mathrm{~nm}$ wavelength using Synergy H5 plate reader. The test evaluation was carried out 176 following the recommended positive and negative cutoffs and test results were interpreted by 177 calculating inhibition rates for samples as follows: Inhibition $=(1$ - O.D. value of sample/O.D. value 178 of negative control) $\times 100 \%$. According to the manufacturer's instructions, neutralizing antibody 179 levels higher than $20 \%$ were considered as positive. 
medRxiv preprint doi: https://doi.org/10.1101/2021.07.23.21261042; this version posted August 8, 2021. The copyright holder for this preprint (which was not certified by peer review) is the author/funder, who has granted medRxiv a license to display the preprint in perpetuity.

It is made available under a CC-BY-ND 4.0 International license.

\subsection{Statistical analysis}

183 We provide summary descriptive analysis using mean, median, standard deviation and interquartile 184 range as appropriate. We fitted generalized additive linear models with plasma IgG levels and neutralizing antibodies as the dependent variables and T2DM status (yes/no), hypertension (yes/no),

186 BMI (categorical: $<25,25-30$, and $>30 \mathrm{~kg} / \mathrm{m}^{2}$ ), age, gender, previous COVID-19 infection (yes/no), 187 comorbidity score (sum score of equal weight for heart disease, stroke, chronic obstructive 188 pulmonary disease, asthma, obstructive sleep apnea, chronic kidney disease, bleeding disorders and 189 other chronic diseases), and duration since receiving the second vaccine dose as the independent

190 variables. We fitted penalized splines for the two continuous variables age and duration since second 191 dose to account for non-linearity using restricted maximum likelihood (REML) estimation. Penalized 192 splines are smoothing nonparametric terms that can maximize the goodness-of-fit by cross-validation 193 and a penalty term for over- and under-fitting. We reported effect estimates with 95\% confidence intervals interpreted as change in average $\mathrm{IgG}$ and neutralizing levels after adjustment.

195 In an additional post-hoc analysis, we also explored interaction analyses looking into the effects of 196 being diabetic across age, gender, BMI, and hypertension categories on the circulating IgG levels.

197 We fitted stratified adjusted models to estimate the change in IgG levels comparing diabetics to non-

198 diabetics. We then included an interaction term between diabetes status and the other variable of 199 interest to examine the Wald-test p-value for statistical significance. All analyses were done in $\mathrm{R}$ 200 software version 3.3.1 (R Foundation for Statistical Computing), penalized splines were implemented 201 in generalized additive models using the $m g c v$ package. A p-value of less than 0.05 was considered to 202 indicate statistical significance.

\section{$203 \quad 3 \quad$ Results}

\section{$204 \quad 3.1 \quad$ Population characteristics}

205 This study included a total of 262 participants; 181 non-diabetics and 81 people diagnosed with 206 T2DM. Of these 262 individuals, 193 were normotensive and 69 were hypertensive. Subdividing 207 based on body mass index (BMI), 65 people had a BMI less than $25 \mathrm{~kg} / \mathrm{m}^{2}$, 117 people had a BMI 
medRxiv preprint doi: https://doi.org/10.1101/2021.07.23.21261042; this version posted August 8, 2021. The copyright holder for this preprint (which was not certified by peer review) is the author/funder, who has granted medRxiv a license to display the preprint in perpetuity.

It is made available under a CC-BY-ND 4.0 International license.

between $25-30 \mathrm{~kg} / \mathrm{m}^{2}$ and 74 had a BMI higher than $30 \mathrm{~kg} / \mathrm{m}^{2}$ (BMI information for 6 individuals

\subsection{SARS-CoV-2 IgG and Neutralizing Antibodies in People with or without T2DM}

213

Analysis of the SARS-CoV-2 IgG and neutralizing antibodies based on T2DM status showed that all

$\mathrm{BAU} / \mathrm{mL}$ which was more than 5 times the cut off for a positive level as recommended by the manufacturer. However, stratifying our cohort based on the T2DM status, people with T2DM had significantly lower levels of SARS-CoV-2 IgG antibodies (138 $\pm 59.4 \mathrm{BAU} / \mathrm{mL})$ compared to people without diabetes $(154 \pm 49.1 \mathrm{BAU} / \mathrm{mL})$ (Figure 1A). Similarly, strong SARS-CoV-2 neutralizing antibody levels were overall observed in our study cohort; however, neutralizing antibody levels stratified by T2DM status are summarized in (Table 1).

After adjustment to potential confounders, on average, people with TD2M had $13.86 \mathrm{BAU} / \mathrm{ml}(95 \%$ $\mathrm{p}=0.036$ ) less neutralizing antibodies than non-diabetics (Table 2).

\subsection{SARS-CoV-2 IgG and Neutralizing Antibodies with regard to Obesity Levels}

Obesity levels also did not significantly affect the levels of SARS-CoV-2 IgG and neutralizing measurements. SARS-CoV2 IgG antibody levels in people with normal weight, overweight, and

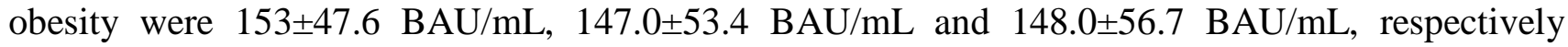

231 (Figure 1C). Similarly, SARS-CoV2 neutralizing antibody levels were also comparable in our study 232 population and the levels in people with normal weight, overweight, and obesity were $86.3 \pm 12.8 \%$, $23384.3 \pm 16.6 \%$, and 84.6 $\pm 13.6 \%$, respectively (Figure 1D). Obesity status did not show a statistically 234 significant difference in regression analyses (Table 2). 
medRxiv preprint doi: https://doi.org/10.1101/2021.07.23.21261042; this version posted August 8, 2021. The copyright holder for this preprint (which was not certified by peer review) is the author/funder, who has granted medRxiv a license to display the preprint in perpetuity.

It is made available under a CC-BY-ND 4.0 International license.

236 Next, we found that the circulating levels of SARS-CoV2 IgG antibodies were comparable between

237 people with or without hypertension. In people with hypertension, SARS-CoV2 IgG antibody levels

238 were relatively lower $(144 \pm 54.8 \mathrm{BAU} / \mathrm{mL})$ compared to those without hypertension $(151 \pm 52.2$

239 BAU/mL) (Figure 1E). Similarly, neutralizing antibody levels also differed between people with

240 hypertension and those without hypertension $(81.7 \pm 17.3 \%$ vs $85.9 \pm 13.8 \%$ ) (Figure 1F). After

241 adjustment to potential confounders, the differences in humoral immunity by hypertension status

242 remained statistically non-significant (Table 2).

243

244

245

246

247

248

249

250

251

252

253

254

255

256

257

258

259

260

261

262

263

264

265

\subsection{SARS-CoV-2 IgG and Neutralizing Antibodies by Gender, Previous COVID-19 Infection, and Age}

Circulating levels of SARS-CoV2 IgG antibodies were not significantly different when compared between male and female ( $\mathrm{p}=0.548)$ (Table 2). Overall, females had a higher SARS-CoV2 IgG antibody level of 154.0 $\pm 50.0 \mathrm{BAU} / \mathrm{mL}$ compared to $144.0 \pm 55.2 \mathrm{BAU} / \mathrm{mL}$ in male (Figure 1G). Similarly, neutralizing antibody levels also differed non-significantly $(\mathrm{p}=0.865)$ (Table 2) between female and male, which were $85.9 \pm 13.5 \%$ vs $83.8 \pm 16.0 \%$, respectively (Figure 1H). Interestingly, those with the previous COVID-19 infection had higher IgG and neutralizing antibody levels (Figure 2) and a net average increase of $38.50 \mathrm{BAU} / \mathrm{ml} \mathrm{IgG} \mathrm{(95 \%} \mathrm{CI:} 23.05$ to $53.96 \mathrm{BAU} / \mathrm{ml}, \mathrm{p}<0.001)$ and 7.11\% neutralizing antibodies (95\% CI: 2.31 to $11.91 \%, \mathrm{p}=0.004)$. Regarding participant age, each one year increase in age was associated with $-0.43 \mathrm{BAU} / \mathrm{ml}(95 \% \mathrm{CI}$ : -0.86 to $0, \mathrm{p}=0.049)$ and $0.25 \%$ decrease in neutralizing antibodies (95\% CI: -0.38 to $-0.12 \%, \mathrm{p}<0.001)$ (Table.2).

\subsection{Additional Analyses}

Generally, IgG and neutralizing antibodies levels declined as more days passed after receiving the second vaccine dose. Antibodies-duration adjusted smooth relationships with $95 \%$ confidence intervals are presented in (Figure 3). Diabetes and hypertensive status did not show considerable deviation from the linear decline over time, nor did we notice any appreciable change in slope between different subgroups. Regression estimates using $\operatorname{IgM}$ antibodies as the outcome also did not show any significant differences between diabetics and non-diabetics (Supplemental Table S1). In the interaction analyses, across all groups, being diabetic was consistently associated with lower IgG levels as compared to non-diabetics (Supplemental Figure S1). However, the interaction terms between diabetes status and the other variables (age, gender, previous COVID-19 infection, BMI and hypertension) were not powered to result in statistically significant p-values. 
medRxiv preprint doi: https://doi.org/10.1101/2021.07.23.21261042; this version posted August 8, 2021. The copyright holder for this preprint (which was not certified by peer review) is the author/funder, who has granted medRxiv a license to display the preprint in perpetuity.

It is made available under a CC-BY-ND 4.0 International license.

\section{Discussion}

270 Kuwait launched its COVID-19 mass vaccination program back in December 2020, starting from

271 priority groups at high risk including the elderly (> 65 years), health care providers, vulnerable 272 people with chronic underlying morbidities, members of armed forces, and others. As of now, as per 273 the ministry of health $(\mathrm{MOH})$ resources, 34\% eligible people in the country have been vaccinated 274 with at least one dose of COVID-19 vaccine and 21.26\% received two doses [14]. The mass 275 vaccination program in the country included first the BNT162b2 (Pfizer-BioNTech) mRNA vaccine and later, other COVID-19 vaccines such as adenovirus-based AstraZeneca vaccine and mRNAbased Moderna vaccine were also included. To the best of our knowledge, there has been no nationwide study looking at the humoral immune responses in the BNT162b2 recipients who have completed their COVID-19 vaccination. Therefore, in the present study, we have evaluated SARSCoV-2-specific antibody responses after two doses of BNT162b2 (Pfizer-BioNTech) mRNA vaccine in a diverse cohort of 262 adult people, aged $49.7 \pm 15.1$ years. We compared SARS-CoV-2-specific IgG and neutralizing antibody responses in these individuals with regard to T2DM status, hypertension, level of obesity, gender, and the duration after second dose.

Humoral immune response is the key component of adaptive immunity to viral infections [15]. Our data show the robust levels of SARS-CoV-2-specific IgG and neutralizing antibodies, elicited after immunization with BNT162b2 (Pfizer-BioNTech) mRNA vaccine, and titers were nearly 5 times the threshold level for seropositivity. Notably, T cell-dependent antibody response typically initiates with the production of $\operatorname{IgM}$ and later progresses with the expression of other immunoglobulin isotypes including IgG and IgA; all of which may mediate virus (SARS-CoV-2) neutralization $[16 ; 17 ; 18]$. $\operatorname{IgM}$ antibodies are produced early as they do not require B cells to undergo somatic hypermutation or class switch recombination, express low affinity and due to their larger size (pentamers), they are mainly found in the blood [19]. Rapid synthesis of IgM, compared to other immunoglobulin isotypes,

293 is specifically important for infection control at the early stages via effective activation of the complement system [20]. Indeed, IgG is the major antibody isotype present in blood and extracellular fluid, while $\operatorname{Ig} \mathrm{A}$ is the main isotype found in secretions which makes it critical for defense against 
medRxiv preprint doi: https://doi.org/10.1101/2021.07.23.21261042; this version posted August 8, 2021. The copyright holder for this preprint (which was not certified by peer review) is the author/funder, who has granted medRxiv a license to display the preprint in perpetuity.

It is made available under a CC-BY-ND 4.0 International license.

pathogens at portals of respiratory and gastro-intestinal epithelia. IgG efficiently opsonizes pathogens

for removal by phagocytosis and/or by complement activation whereas $\operatorname{IgA}$ is a potent actor as a neutralizing antibody [21]; accordingly, $\operatorname{IgA}$ has been found to dominate the early neutralizing antibody response to SARS-CoV-2 infection [22; 23].

300

301

302

303

304

305

306

307

308

309

310

311

312

313

314

315

316

317

318

319

320

321

322

323

324

325

326

BNT162b2 vaccine is based on lipid nanoparticles formulated mRNA that encodes the full-length spike (S) protein of SARS-CoV-2 [24]. Vaccine-induced, high-affinity IgG and IgA neutralizing antibodies can inhibit the infectivity of SARS-CoV-2 by directly blocking viral attachment to host cell ACE2 receptors and preventing its entry into host cells [25; 26]. Given that BNT162b2 vaccine delivers mRNA encoding only for the SARS-CoV-2 S-glycoprotein, it would however induce the production of anti-S-RBD IgG antibodies but not anti-N IgG antibodies [27]. SARS-CoV-2 anti-N IgG antibodies are a known marker/ indicator of seroconversion after disease exposure, while the presence of SARS-CoV-2 IgG antibodies indicates seroconversion after either disease exposure or immunization [28]. Our data show robust SARS-CoV-2 IgG and neutralizing antibody levels in vaccinees after two-doses of BNT162b2 mRNA vaccine, suggesting an efficient antigen processing and presentation in all these people, which is in agreement with several other studies of BNT162b2 vaccination in diverse population cohorts $[13 ; 29 ; 30]$.

Although, we observed high titers of anti-RBD IgG antibodies in the BNT162b2 vaccinees, these data still do not allow affirmative conclusions to be drawn as to the role of these antibodies in immunoprotection from COVID-19. The elicited anti-RBD immune response is polyclonal, nonetheless, each immunoglobulin isotype cannot be expected to play a protective role against postvaccination SARS-CoV-2 exposure. Since there is substantial evidence for a strong positive correlation between virus neutralization assays and RBD-specific antibodies-mediated inhibition of the interaction between SARS-CoV-2 spike (S1) protein and host cell ACE2 receptor [31], we set out to measure the neutralizing antibodies that inhibited the interaction between RBD and ACE2 in a surrogate VNT and high levels of neutralizing antibodies detected in immune sera indicate that the BNT162b2 mRNA vaccine elicits protective immunity in vaccinees. In line with our findings, Pratesi et al. showed that BNT162b2 mRNA vaccine was able to induce increased levels of high-avidity, anti-RBD IgG and IgA and protective neutralizing antibodies in the vaccinated individuals [13].

Herein, we assessed whether the presence of T2DM affects the capability to mount an efficient humoral immune response against BNT162b2 mRNA vaccine. The data show that increased levels of anti-RBD IgG and neutralizing antibodies were present in both diabetics and non-diabetics. Notably, 
medRxiv preprint doi: https://doi.org/10.1101/2021.07.23.21261042; this version posted August 8, 2021. The copyright holder for this preprint (which was not certified by peer review) is the author/funder, who has granted medRxiv a license to display the preprint in perpetuity.

It is made available under a CC-BY-ND 4.0 International license.

our data obtained from SARS-CoV-2 vaccinees are consistent, at least in part, with another study by Lampasona et al. reporting that humoral immune response against SARS-CoV-2 in patients with diabetes was present and superimposable, regarding timing and antibody titers, to that of non-diabetic patients [32]. However, we found that levels of RBD-specific IgG and neutralizing antibodies were significantly lower in diabetics than non-diabetics which may be explained by the fact that hyperglycemia and insulin resistance are known to induce several immune defects, such as impairment in monocyte/macrophage and neutrophil function, reduced lymphocyte proliferative responses, defective antigen presentation, and complement activation dysfunction [33]. Our findings of the lower humoral responses in vaccinees with T2DM are corroborated by Yelin et al. who found that Pfizer BNT162b2 vaccination had relatively similar effectiveness across age groups (16-80 years old), however, specific chronic comorbidities, such as T2DM, hypertension, chronic obstructive pulmonary disease (COPD), and immunosuppression were inversely associated with vaccine efficacy [34].

Next, we observed that SARS-CoV-2 IgG and neutralizing antibody levels did not differ significantly among BNT162b2 vaccinees with regard to obesity levels, age, and gender. In partial agreement with our findings, a study analyzing the antibody titers at 7 days after the second dose of BNT162b2 vaccine in a group of 248 healthcare workers reported that age and gender significantly impacted the vaccination outcome as young female participants exhibited increased humoral immune responses while BMI and hypertension did not seem to associate with difference in immune response to vaccination [35]. Pragmatically, we ought not rule out that studies of larger cohorts may unveil statistically significant differences associated with age, gender, and obesity levels.

More importantly, we found that levels of SARS-CoV-2 IgG and neutralizing antibodies were significantly higher in people who had previously had COVID-19 infection. This is comprehensible as the persons who recovered from COVID-19 infection are expected to elicit efficient humoral immunity due to the pre-existing memory B-cell responses to SARS-CoV-2 . In agreement, a large cohort (n=1090) study of BNT162b2 (Pfizer-BioNTech) mRNA vaccine recipients found that the SRBD-specific IgG and neutralizing antibody levels were higher in individuals who were previously infected with SARS-CoV-2 compared to those without prior infection. Based on these results, the authors suggested that a single dose of BNT162b2 Pfizer-BioNTech vaccine was adequate for individuals with prior SARS-CoV-2 infection, toward considering anti-S IgG antibody levels as well 
medRxiv preprint doi: https://doi.org/10.1101/2021.07.23.21261042; this version posted August 8, 2021. The copyright holder for this preprint (which was not certified by peer review) is the author/funder, who has granted medRxiv a license to display the preprint in perpetuity.

It is made available under a CC-BY-ND 4.0 International license.

357

358

359

360

361

362

363

364

365

366

367

368

369

370

371

372

373

374

375

376

377

378

379

380

381

382

383

384

385

potential for neutralizing capability of elicited antibodies [36]. Similar findings were reported by several other studies involving diverse cohorts of various sizes [37;38].

This study has a number of limitations. First, the population examined were self-selected mostly by word of mouth and recruitment advertisements. It is likely that the sample is over-representing comorbid individuals who actively sought to know the antibody protection levels they have after vaccination. Second, the regression analyses adjusted for a number of a priori confounders, however, we cannot rule out potential residual confounding by severity of illness. For example, we could not assess whether patients with severe uncontrolled diabetes or uncontrolled hypertension show lower response to vaccine-induced humoral immunity. Third, the small sample size also limited our ability to examine the effects among different subgroups. The interaction analyses were likely underpowered to detect statistically significant differences between different strata. Fourth, the data presented represent a cross-sectional analysis of the humoral response only, therefore, further studies will be required including the longitudinal analyses of both humoral and cellular responses in the BNT162b2 vaccinees since longer-time follow-ups of both arms of the adaptive immunity can provide more precise information of the putative duration of protective immunity after vaccination. Finally, the studied population in Kuwait is likely to be homogenous and therefore the readers should be cautioned when generalizing the results to other settings and populations. We aim to further perform larger-cohort, multi-center studies analyzing both antibody persistence and presence of memory immune cell populations.

\section{Conclusion}

Taken together, our data support the presence of robust SARS-CoV-2-specific IgG and neutralizing antibody responses in people with and without T2DM, following two doses of Pfizer-BioNTech BNT162b2 mRNA vaccine against COVID-19. Notwithstanding, people with diabetes had significantly lower antibody titers than their non-diabetic counterparts; whereas, level of hypertension, obesity or gender did not show significant effect on antibody titers. Besides, continuous monitoring of SARS-CoV-2-specific IgG and neutralizing antibody profiling may be a pragmatic approach to guide personalized needs for booster shots for the maintenance of adaptive immunity in COVID-19 vaccinees.

\section{Conflict of Interest}


medRxiv preprint doi: https://doi.org/10.1101/2021.07.23.21261042; this version posted August 8, 2021. The copyright holder for this preprint (which was not certified by peer review) is the author/funder, who has granted medRxiv a license to display the preprint in perpetuity.

It is made available under a CC-BY-ND 4.0 International license .

386 The authors declare that the research was conducted in the absence of any commercial or financial

387 relationships that could be construed as a potential conflict of interest.

$388 \quad 7 \quad$ Author Contributions

389 H.A., A.T. and SS Conceived and designed the analysis, researched data and wrote the manuscript.

390 BA performed the analysis and generated the figures. M.H.1 involved in sample collection and

391 laboratory analysis. S.S., M.G., M.J., A.A.1, A.A.2, M.M. and M.H.2 involved in subjects'

392 recruitment and reviewed/edited the manuscript. I.A. and P.C. performed laboratory analysis. S.D.

393 involved in data collection and managed recruitment. R.A. edited the manuscript. J.A., M.A. and

394 F.A. contributed to the discussion and reviewed/edited the manuscript. All authors read and approved

395 the manuscript. M.A. is the guarantor of this work and, as such, had full access to all the data in the 396 study and takes responsibility for the integrity of the data and the accuracy of the data analysis.

\section{Funding}

398 This Study was funded by Kuwait Foundation for the Advancement of Sciences (KFAS) grant (RA

399 HM-2021-008). 
medRxiv preprint doi: https://doi.org/10.1101/2021.07.23.21261042; this version posted August 8, 2021. The copyright holder for this preprint (which was not certified by peer review) is the author/funder, who has granted medRxiv a license to display the preprint in perpetuity.

It is made available under a CC-BY-ND 4.0 International license .

Figures
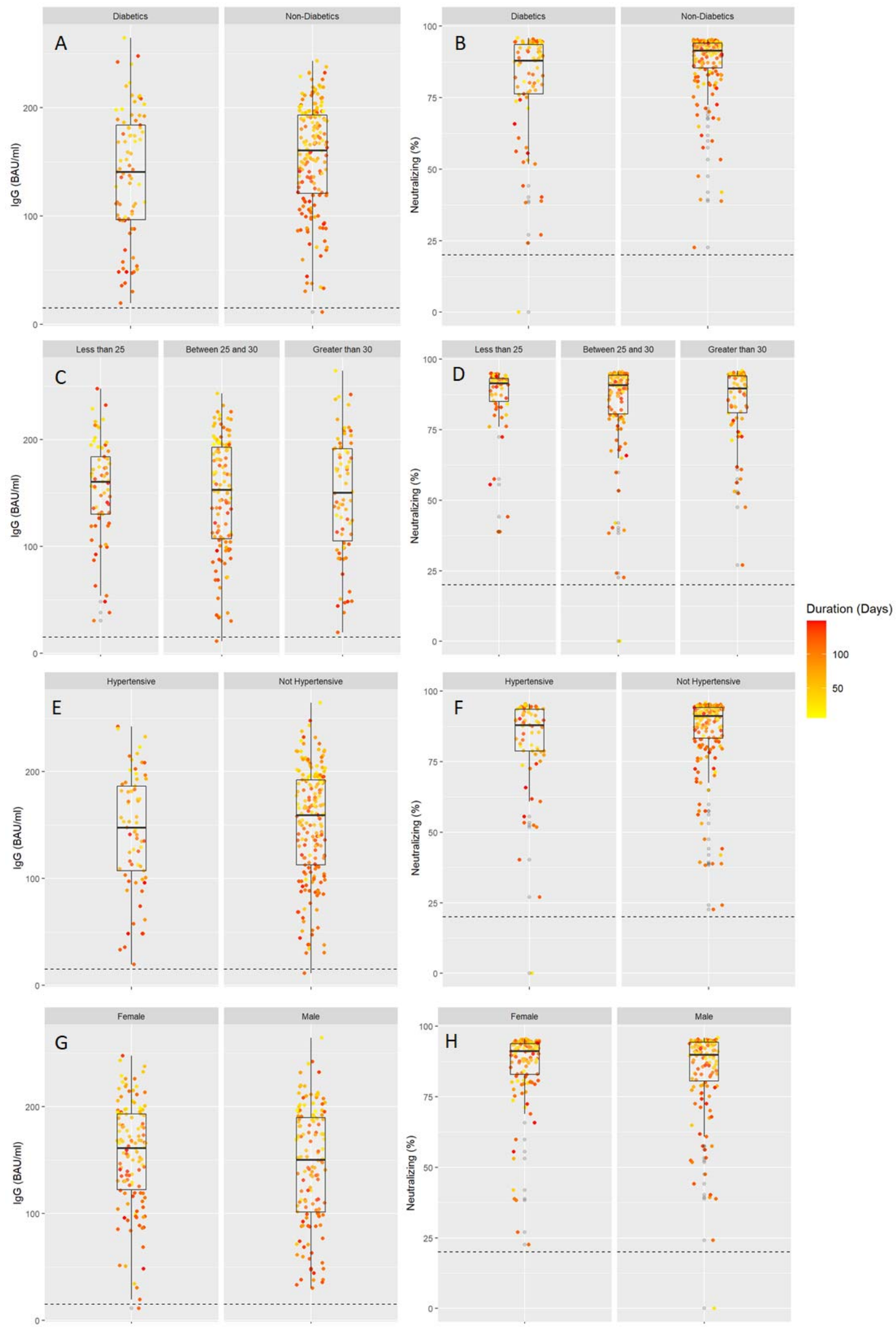
medRxiv preprint doi: https://doi.org/10.1101/2021.07.23.21261042; this version posted August 8, 2021. The copyright holder for this preprint (which was not certified by peer review) is the author/funder, who has granted medRxiv a license to display the preprint in perpetuity.

It is made available under a CC-BY-ND 4.0 International license .

402 Figure 1: SARS-COV2 IgG and neutralizing antibodies in individuals stratified by diabetes (panels 403 A and B), obesity levels (panels C and D), hypertension (panels E and F) and gender (panels G and $404 \mathrm{H}$ ). All individuals took two doses of BNT162b2 (Pfizer-BioNTech) vaccine and this was plotted 405 with days since vaccination shown based on the color intensity.

406

407
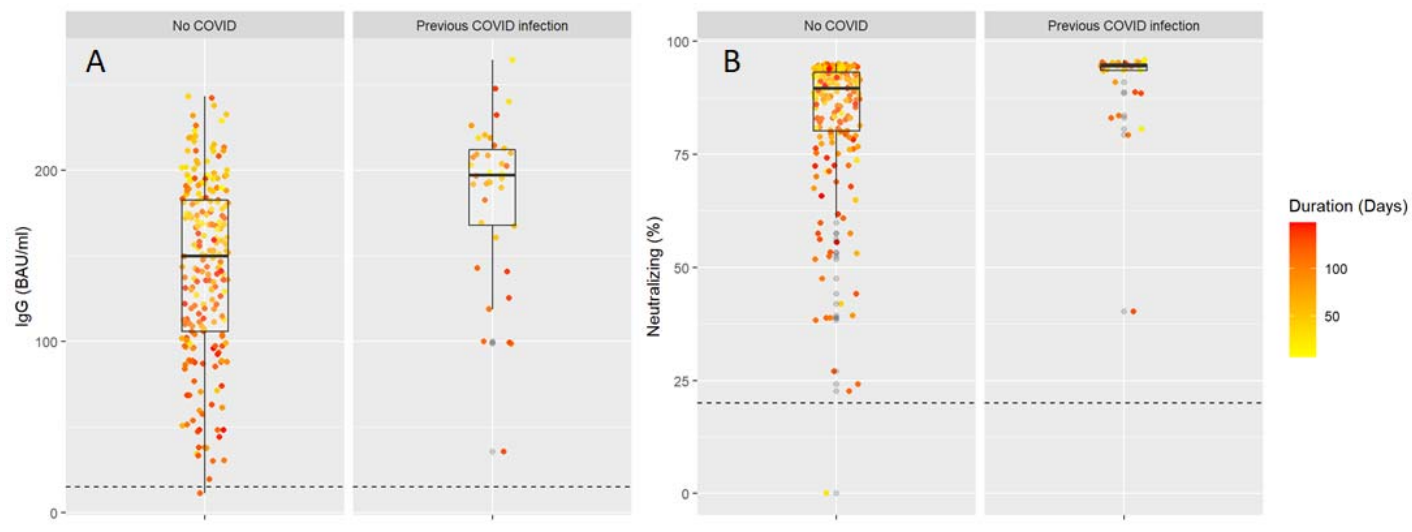

409 Figure 2: SARS-COV2 IgG (panel A) and neutralizing antibodies (panel B) in individuals with a 410 previous COVID-19 infection. All individuals took two doses of BNT162b2 (Pfizer-BioNTech) 411 vaccine and this was plotted with days since vaccination shown based on the color intensity. 
medRxiv preprint doi: https://doi.org/10.1101/2021.07.23.21261042; this version posted August 8, 2021. The copyright holder for this preprint (which was not certified by peer review) is the author/funder, who has granted medRxiv a license to display the preprint in perpetuity.

It is made available under a CC-BY-ND 4.0 International license .
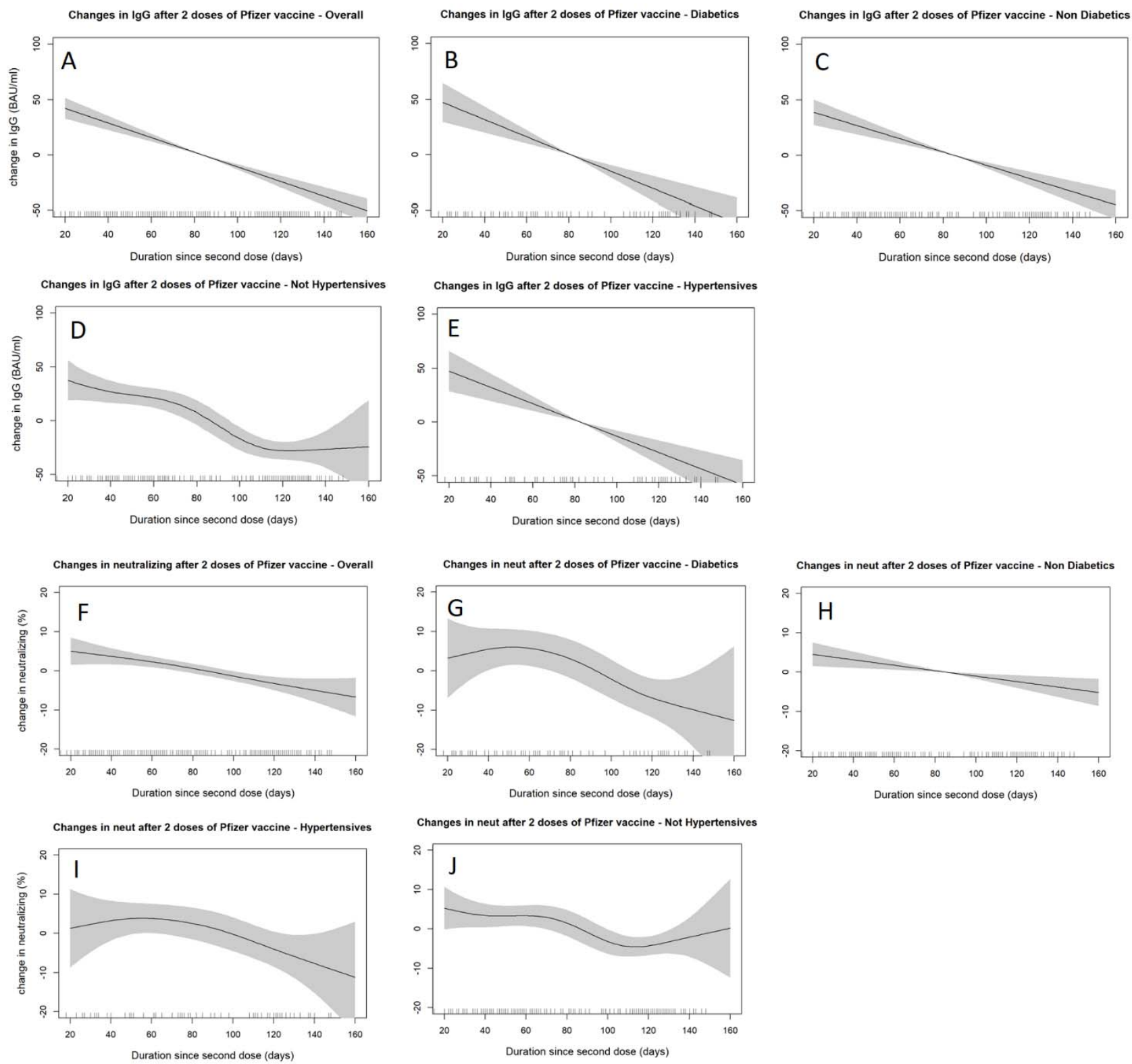

418 Figure 3: SARS-COV2 IgG (panels A-E) and neutralizing antibodies (panels F-J) decline over time 419 since receiving the second dose of BNT162b2 (Pfizer-BioNTech) vaccine stratified by diabetes and 420 hypertension status. The smooth relationships were derived from generalized additive models with 421 penalized splines for duration (in days) and adjusted for age, gender, BMI, hypertension, diabetes 422 status, comorbidity scores and previous COVID-19 infections. Solid lines represent the effect 423 estimates of change over time while the shaded areas represent the $95 \%$ confidence intervals. 
medRxiv preprint doi: https://doi.org/10.1101/2021.07.23.21261042; this version posted August 8, 2021. The copyright holder for this preprint (which was not certified by peer review) is the author/funder, who has granted medRxiv a license to display the preprint in perpetuity.

It is made available under a CC-BY-ND 4.0 International license.

426 Table 1. Clinical characteristics and SARS-CoV2 serological findings in studied groups stratified by type-2

427 diabetes mellitus status.

\begin{tabular}{|c|c|c|c|}
\hline & $\begin{array}{l}\text { Non-Diabetics } \\
\qquad(\mathbf{N}=181)\end{array}$ & $\begin{array}{l}\text { Diabetics } \\
(\mathrm{N}=\mathbf{8 1})\end{array}$ & $\begin{array}{l}\text { Overall } \\
(\mathrm{N}=262)\end{array}$ \\
\hline \multicolumn{4}{|l|}{ Age (years) } \\
\hline Mean (SD) & $45.4(14.3)$ & $59.4(12.0)$ & $49.7(15.1)$ \\
\hline Median [Min, Max] & $43.1[22.0,121]$ & $60.3[24.4,81.2]$ & $50.3[22.0,121]$ \\
\hline \multicolumn{4}{|l|}{ Gender } \\
\hline Female & $92(50.8 \%)$ & $34(42.0 \%)$ & $126(48.1 \%)$ \\
\hline Male & $89(49.2 \%)$ & $47(58.0 \%)$ & $136(51.9 \%)$ \\
\hline \multicolumn{4}{|l|}{ BMI categories } \\
\hline Less than 25 & $51(28.2 \%)$ & $14(17.3 \%)$ & $65(24.8 \%)$ \\
\hline Between 25 and 30 & $83(45.9 \%)$ & $34(42.0 \%)$ & $117(44.7 \%)$ \\
\hline Greater than 30 & $43(23.8 \%)$ & $31(38.3 \%)$ & $74(28.2 \%)$ \\
\hline Missing & $4(2.2 \%)$ & $2(2.5 \%)$ & $6(2.3 \%)$ \\
\hline \multicolumn{4}{|l|}{ Hypertension } \\
\hline No & $151(83.4 \%)$ & $42(51.9 \%)$ & $193(73.7 \%)$ \\
\hline Yes & $30(16.6 \%)$ & $39(48.1 \%)$ & $69(26.3 \%)$ \\
\hline \multicolumn{4}{|l|}{ Comorbidity score } \\
\hline Mean (SD) & $0.320(0.594)$ & $0.469(0.896)$ & $0.366(0.703)$ \\
\hline Median [Min, Max] & $0[0,3.00]$ & $0[0,5.00]$ & $0[0,5.00]$ \\
\hline \multicolumn{4}{|c|}{ Previous infection of COVID 19} \\
\hline No & $155(85.6 \%)$ & $69(85.2 \%)$ & $224(85.5 \%)$ \\
\hline Yes & $26(14.4 \%)$ & $12(14.8 \%)$ & $38(14.5 \%)$ \\
\hline \multicolumn{4}{|c|}{ Duration since second dose } \\
\hline Mean (SD) & $84.3(37.1)$ & $81.5(37.4)$ & $83.4(37.2)$ \\
\hline Median [Min, Max] & $82.0[7.00,148]$ & $81.0[13.0,148]$ & $82.0[7.00,148]$ \\
\hline \multicolumn{4}{|l|}{ IgG (BAU/ml) } \\
\hline Mean (SD) & $154(49.1)$ & $138(59.4)$ & 149 (52.9) \\
\hline Median [Min, Max] & $160[11.0,243]$ & $140[19.3,264]$ & $156[11.0,264]$ \\
\hline \multicolumn{4}{|l|}{ IgM (BAU/ml) } \\
\hline Mean (SD) & $65.6(84.2)$ & $58.1(112)$ & $63.3(93.6)$ \\
\hline Median [Min, Max] & $31.3[0.600,600]$ & $30.5[0,800]$ & $31.0[0,800]$ \\
\hline \multicolumn{4}{|c|}{ Neutralizing antibodies (\%) } \\
\hline Mean (SD) & $87.1(11.6)$ & $79.7(19.5)$ & $84.8(14.9)$ \\
\hline Median [Min, Max] & $91.5[22.6,95.3]$ & $88.0[0,95.8]$ & $90.9[0,95.8]$ \\
\hline Missing & $3(1.7 \%)$ & $0(0 \%)$ & $3(1.1 \%)$ \\
\hline
\end{tabular}


medRxiv preprint doi: https://doi.org/10.1101/2021.07.23.21261042; this version posted August 8, 2021. The copyright holder for this preprint (which was not certified by peer review) is the author/funder, who has granted medRxiv a license to display the preprint in perpetuity.

It is made available under a CC-BY-ND 4.0 International license .

Table2. Multiple linear regression analyses showing average changes of SARS-CoV2 IgG and neutralizing antibodies.

431

\begin{tabular}{|c|c|c|c|c|c|c|}
\hline \multirow[b]{2}{*}{ Variable } & \multicolumn{3}{|c|}{$\operatorname{IgG}(\mathrm{BAU} / \mathrm{ml}) *$} & \multicolumn{3}{|c|}{ Neutralizing $(\%) *$} \\
\hline & Change & $95 \% \mathrm{CI}$ & p-value & Change & $95 \% \mathrm{CI}$ & p-value \\
\hline Diabetic vs. Non-Diabetic & -13.86 & {$[-27.08$ to -0.64$]$} & 0.041 & -4.42 & {$[-8.53$ to -0.32$]$} & 0.036 \\
\hline Hypertensive vs. Not Hypertensive & 4.00 & [-9.95 to 17.95$]$ & 0.575 & 0.75 & {$[-3.59$ to 5.1$]$} & 0.734 \\
\hline Age (per 1 year increase) & -0.43 & {$[-0.86$ to 0$]$} & 0.049 & -0.25 & {$[-0.38$ to -0.12$]$} & $<0.001$ \\
\hline Male vs. Female & -3.52 & [-15 to 7.96$]$ & 0.548 & -0.31 & [-3.87 to 3.26$]$ & 0.865 \\
\hline BMI between 25 and 30 vs. BMI $<25$ & -8.70 & {$[-22.58$ to 5.19$]$} & 0.221 & -1.91 & [-6.29 to 2.46$]$ & 0.392 \\
\hline BMI Greater than 30 vs. BMI $<25$ & -5.76 & [-21.57 to 10.05$]$ & 0.476 & -0.33 & [-5.3 to 4.63$]$ & 0.895 \\
\hline Previous COVID-19 Infection vs. None & 38.50 & {$[23.05$ to 53.96$]$} & $<0.001$ & 7.11 & [2.31 to 11.91$]$ & 0.004 \\
\hline Comorbidity score (per 1 score increase) & 4.99 & {$[-3.12$ to 13.1$]$} & 0.229 & 1.21 & [-1.35 to 3.77$]$ & 0.354 \\
\hline
\end{tabular}

*All models were adjusted for the variables mentioned in addition to duration since second dose of BNT162b2 
medRxiv preprint doi: https://doi.org/10.1101/2021.07.23.21261042; this version posted August 8, 2021. The copyright holder for this preprint (which was not certified by peer review) is the author/funder, who has granted medRxiv a license to display the preprint in perpetuity.

It is made available under a CC-BY-ND 4.0 International license.

\section{References}

461

462

463

464

465

466

467

468

469

470

471

472

473

474

475

476

477

478

479

480

481

482

483

484

485

486

487

488

489

490

491

492

493

494

495

496

497

[1] E. Dong, H. Du, and L. Gardner, An interactive web-based dashboard to track COVID-19 in real time. Lancet Infect Dis (2020).

[2] A. Alshukry, H. Ali, Y. Ali, T. Al-Taweel, M. Abu-Farha, J. AbuBaker, S. Devarajan, A.A. Dashti, A. Bandar, H. Taleb, A. Al Bader, N.Y. Aly, E. Al-Ozairi, F. Al-Mulla, and M. Bu Abbas, Clinical characteristics of coronavirus disease 2019 (COVID-19) patients in Kuwait. PLoS One 15 (2020) e0242768.

[3] B. Alahmad, A.A. Al-Shammari, A. Bennakhi, F. Al-Mulla, and H. Ali, Fasting Blood Glucose and COVID-19 Severity: Nonlinearity Matters. Diabetes Care 43 (2020) 3113-3116.

[4] A. Alshukry, M. Bu Abbas, Y. Ali, B. Alahmad, A.A. Al-Shammari, G. Alhamar, M. Abu-Farha, J. AbuBaker, S. Devarajan, A.A. Dashti, F. Al-Mulla, and H. Ali, Clinical characteristics and outcomes of COVID-19 patients with diabetes mellitus in Kuwait. Heliyon 7 (2021) e06706.

[5] C.N. Lumeng, Innate immune activation in obesity. Mol Aspects Med 34 (2013) 12-29.

[6] M. Abu-Farha, F. Al-Mulla, T.A. Thanaraj, S. Kavalakatt, H. Ali, M. Abdul Ghani, and J. Abubaker, Impact of Diabetes in Patients Diagnosed With COVID-19. Front Immunol 11 (2020) 576818.

[7] J. Pérez-Galarza, C. Prócel, C. Cañadas, D. Aguirre, R. Pibaque, R. Bedón, F. Sempértegui, H. Drexhage, and L. Baldeón, Immune Response to SARS-CoV-2 Infection in Obesity and T2D: Literature Review. Vaccines 9 (2021) 102.

[8] E.A. Al-Suhaimi, and A. Shehzad, Leptin, resistin and visfatin: the missing link between endocrine metabolic disorders and immunity. European Journal of Medical Research 18 (2013) 12.

[9] C.B. Guest, M.J. Park, D.R. Johnson, and G.G. Freund, The implication of proinflammatory cytokines in type 2 diabetes. Front Biosci 13 (2008) 5187-94.

[10] Y. Tang, J. Liu, D. Zhang, Z. Xu, J. Ji, and C. Wen, Cytokine Storm in COVID-19: The Current Evidence and Treatment Strategies. Frontiers in immunology 11 (2020) 1708-1708.

[11] A. Fara, Z. Mitrev, R.A. Rosalia, and B.M. Assas, Cytokine storm and COVID-19: a chronicle of pro-inflammatory cytokines. Open Biol 10 (2020) 200160.

[12] E.E. Walsh, R.W. Frenck, Jr., A.R. Falsey, N. Kitchin, J. Absalon, A. Gurtman, S. Lockhart, K. Neuzil, M.J. Mulligan, R. Bailey, K.A. Swanson, P. Li, K. Koury, W. Kalina, D. Cooper, C. Fontes-Garfias, P.Y. Shi, O. Tureci, K.R. Tompkins, K.E. Lyke, V. Raabe, P.R. Dormitzer, K.U. Jansen, U. Sahin, and W.C. Gruber, Safety and Immunogenicity of Two RNA-Based Covid-19 Vaccine Candidates. The New England journal of medicine 383 (2020) 2439-2450.

[13] F. Pratesi, T. Caruso, D. Testa, T. Tarpanelli, A. Gentili, D. Gioe, and P. Migliorini, BNT162b2 mRNA SARS-CoV-2 Vaccine Elicits High Avidity and Neutralizing Antibodies in Healthcare Workers. Vaccines (Basel) 9 (2021).

[14] E. Mathieu, H. Ritchie, E. Ortiz-Ospina, M. Roser, J. Hasell, C. Appel, C. Giattino, and L. Rodes-Guirao, A global database of COVID-19 vaccinations. Nat Hum Behav (2021). 
medRxiv preprint doi: https://doi.org/10.1101/2021.07.23.21261042; this version posted August 8, 2021. The copyright holder for this preprint (which was not certified by peer review) is the author/funder, who has granted medRxiv a license to display the preprint in perpetuity. It is made available under a CC-BY-ND 4.0 International license .

498

499

500

501

502

503

504

505

506

507

508

509

510

511

512

513

514

515

516

517

518

519

520

521

522

523

524

525

526

527

528

529

530

531

532

533

534

535

536

537

538

539

[15] T. Dorner, and A. Radbruch, Antibodies and B cell memory in viral immunity. Immunity 27 (2007) 384-92.

[16] J. Klingler, S. Weiss, V. Itri, X. Liu, K.Y. Oguntuyo, C. Stevens, S. Ikegame, C.T. Hung, G. Enyindah-Asonye, F. Amanat, I. Baine, S. Arinsburg, J.C. Bandres, E.M. Kojic, J. Stoever, D. Jurczyszak, M. Bermudez-Gonzalez, A. Nadas, S. Liu, B. Lee, S. Zolla-Pazner, and C.E. Hioe, Role of IgM and IgA Antibodies in the Neutralization of SARS-CoV-2. medRxiv (2020).

[17] K. Maeda, N. Higashi-Kuwata, N. Kinoshita, S. Kutsuna, K. Tsuchiya, S.I. Hattori, K. Matsuda, Y. Takamatsu, H. Gatanaga, S. Oka, H. Sugiyama, N. Ohmagari, and H. Mitsuya, Neutralization of SARS-CoV-2 with IgG from COVID-19-convalescent plasma. Sci Rep 11 (2021) 5563.

[18] J. Campillo-Luna, A.V. Wisnewski, and C.A. Redlich, Human $\operatorname{IgG}$ and $\operatorname{IgA}$ responses to COVID-19 mRNA vaccines. medRxiv (2021) 2021.03.23.21254060.

[19] H.W. Schroeder, Jr., and L. Cavacini, Structure and function of immunoglobulins. J Allergy Clin Immunol 125 (2010) S41-52.

[20] A. Sörman, L. Zhang, Z. Ding, and B. Heyman, How antibodies use complement to regulate antibody responses. Molecular Immunology 61 (2014) 79-88.

[21] R. Jefferis, Structure-function relationships in human immunoglobulins. Neth J Med 39 (1991) 188-98.

[22] D. Sterlin, A. Mathian, M. Miyara, A. Mohr, F. Anna, L. Claër, P. Quentric, J. Fadlallah, H. Devilliers, P. Ghillani, C. Gunn, R. Hockett, S. Mudumba, A. Guihot, C.-E. Luyt, J. Mayaux, A. Beurton, S. Fourati, T. Bruel, O. Schwartz, J.-M. Lacorte, H. Yssel, C. Parizot, K. Dorgham, P. Charneau, Z. Amoura, and G. Gorochov, IgA dominates the early neutralizing antibody response to SARS-CoV-2. Science Translational Medicine 13 (2021) eabd2223.

[23] A.V. Wisnewski, J. Campillo Luna, and C.A. Redlich, Human IgG and IgA responses to COVID-19 mRNA vaccines. PloS one 16 (2021) e0249499.

[24] M. Jeyanathan, S. Afkhami, F. Smaill, M.S. Miller, B.D. Lichty, and Z. Xing, Immunological considerations for COVID-19 vaccine strategies. Nature reviews. Immunology 20 (2020) 615-632.

[25] A. Lange, A. Borowik, J. Bochenska, J. Rossowska, and E. Jaskula, Immune Response to COVID-19 mRNA Vaccine-A Pilot Study. Vaccines (Basel) 9 (2021).

[26] A. Padoan, L. Dall'Olmo, F.D. Rocca, F. Barbaro, C. Cosma, D. Basso, A. Cattelan, V. Cianci, and M. Plebani, Antibody response to first and second dose of BNT162b2 in a cohort of characterized healthcare workers. Clin Chim Acta 519 (2021) 60-63.

[27] U. Sahin, A. Muik, E. Derhovanessian, I. Vogler, L.M. Kranz, M. Vormehr, A. Baum, K. Pascal, J. Quandt, D. Maurus, S. Brachtendorf, V. Lorks, J. Sikorski, R. Hilker, D. Becker, A.K. Eller, J. Grutzner, C. Boesler, C. Rosenbaum, M.C. Kuhnle, U. Luxemburger, A. Kemmer-Bruck, D. Langer, M. Bexon, S. Bolte, K. Kariko, T. Palanche, B. Fischer, A. Schultz, P.Y. Shi, C. Fontes-Garfias, J.L. Perez, K.A. Swanson, J. Loschko, I.L. Scully, M. Cutler, W. Kalina, C.A. Kyratsous, D. Cooper, P.R. Dormitzer, K.U. Jansen, and O. Tureci, COVID-19 vaccine BNT162b1 elicits human antibody and TH1 T cell responses. Nature 586 (2020) 594-599. 
medRxiv preprint doi: https://doi.org/10.1101/2021.07.23.21261042; this version posted August 8, 2021. The copyright holder for this preprint (which was not certified by peer review) is the author/funder, who has granted medRxiv a license to display the preprint in perpetuity. It is made available under a CC-BY-ND 4.0 International license .

[28] J. Seow, C. Graham, B. Merrick, S. Acors, S. Pickering, K.J.A. Steel, O. Hemmings, A. O'Byrne, N. Kouphou, R.P. Galao, G. Betancor, H.D. Wilson, A.W. Signell, H. Winstone, C. Kerridge, I. Huettner, J.M. Jimenez-Guardeno, M.J. Lista, N. Temperton, L.B. Snell, K. Bisnauthsing, A. Moore, A. Green, L. Martinez, B. Stokes, J. Honey, A. Izquierdo-Barras, G. Arbane, A. Patel, M.K.I. Tan, L. O'Connell, G. O'Hara, E. MacMahon, S. Douthwaite, G. Nebbia, R. Batra, R. Martinez-Nunez, M. Shankar-Hari, J.D. Edgeworth, S.J.D. Neil, M.H. Malim, and K.J. Doores, Longitudinal observation and decline of neutralizing antibody responses in the three months following SARS-CoV-2 infection in humans. Nat Microbiol 5 (2020) 1598-1607.

[29] P. Jalkanen, P. Kolehmainen, H.K. Häkkinen, M. Huttunen, P.A. Tähtinen, R. Lundberg, S. Maljanen, A. Reinholm, S. Tauriainen, S.H. Pakkanen, I. Levonen, A. Nousiainen, T. Miller, H. Välimaa, L. Ivaska, A. Pasternack, R. Naves, O. Ritvos, P. Österlund, S. Kuivanen, T. Smura, J. Hepojoki, O. Vapalahti, J. Lempainen, L. Kakkola, A. Kantele, and I. Julkunen, COVID-19 mRNA vaccine induced antibody responses against three SARS-CoV-2 variants. Nature Communications 12 (2021) 3991.

[30] J.E. Ebinger, J. Fert-Bober, I. Printsev, M. Wu, N. Sun, J.C. Prostko, E.C. Frias, J.L. Stewart, J.E. Van Eyk, J.G. Braun, S. Cheng, and K. Sobhani, Antibody responses to the BNT162b2 mRNA vaccine in individuals previously infected with SARS-CoV-2. Nature medicine 27 (2021) 981-984.

[31] L. Piccoli, Y.J. Park, M.A. Tortorici, N. Czudnochowski, A.C. Walls, M. Beltramello, C. Silacci-Fregni, D. Pinto, L.E. Rosen, J.E. Bowen, O.J. Acton, S. Jaconi, B. Guarino, A. Minola, F. Zatta, N. Sprugasci, J. Bassi, A. Peter, A. De Marco, J.C. Nix, F. Mele, S. Jovic, B.F. Rodriguez, S.V. Gupta, F. Jin, G. Piumatti, G. Lo Presti, A.F. Pellanda, M. Biggiogero, M. Tarkowski, M.S. Pizzuto, E. Cameroni, C. Havenar-Daughton, M. Smithey, D. Hong, V. Lepori, E. Albanese, A. Ceschi, E. Bernasconi, L. Elzi, P. Ferrari, C. Garzoni, A. Riva, G. Snell, F. Sallusto, K. Fink, H.W. Virgin, A. Lanzavecchia, D. Corti, and D. Veesler, Mapping Neutralizing and Immunodominant Sites on the SARS-CoV-2 Spike Receptor-Binding Domain by Structure-Guided High-Resolution Serology. Cell 183 (2020) 1024-1042 e21.

[32] V. Lampasona, M. Secchi, M. Scavini, E. Bazzigaluppi, C. Brigatti, I. Marzinotto, A. Davalli, A. Caretto, A. Laurenzi, S. Martinenghi, C. Molinari, G. Vitali, L. Di Filippo, A. Mercalli, R. Melzi, C. Tresoldi, P. Rovere-Querini, G. Landoni, F. Ciceri, E. Bosi, and L. Piemonti, Antibody response to multiple antigens of SARS-CoV-2 in patients with diabetes: an observational cohort study. Diabetologia 63 (2020) 2548-2558.

[33] G. Daryabor, M.R. Atashzar, D. Kabelitz, S. Meri, and K. Kalantar, The Effects of Type 2 Diabetes Mellitus on Organ Metabolism and the Immune System. Front Immunol 11 (2020) 1582 .

[34] I. Yelin, R. Katz, E. Herzel, T. Berman-Zilberstein, A. Ben-Tov, J. Kuint, S. Gazit, T. Patalon, G. Chodick, and R. Kishony, Associations of the BNT162b2 COVID-19 vaccine effectiveness with patient age and comorbidities. medRxiv (2021) 2021.03.16.21253686.

[35] R. Pellini, A. Venuti, F. Pimpinelli, E. Abril, G. Blandino, F. Campo, L. Conti, A. De Virgilio, F. De Marco, E.G. Di Domenico, O. Di Bella, S. Di Martino, F. Ensoli, D. Giannarelli, C. Mandoj, V. Manciocco, P. Marchesi, F. Mazzola, S. Moretto, G. Petruzzi, F. Petrone, B. Pichi, M. Pontone, J. Zocchi, A. Vidiri, B. Vujovic, G. Piaggio, A. Morrone, and G. Ciliberto, Initial observations on age, gender, BMI and hypertension in antibody responses to SARSCoV-2 BNT162b2 vaccine. EClinicalMedicine 36 (2021) 100928. 
medRxiv preprint doi: https://doi.org/10.1101/2021.07.23.21261042; this version posted August 8, 2021. The copyright holder for this preprint (which was not certified by peer review) is the author/funder, who has granted medRxiv a license to display the preprint in perpetuity. It is made available under a CC-BY-ND 4.0 International license .

[36] J.E. Ebinger, J. Fert-Bober, I. Printsev, M. Wu, N. Sun, J.C. Prostko, E.C. Frias, J.L. Stewart, J.E. Van Eyk, J.G. Braun, S. Cheng, and K. Sobhani, Antibody responses to the BNT162b2 mRNA vaccine in individuals previously infected with SARS-CoV-2. Nature medicine 27 (2021) 981-984.

[37] C. Manisty, A.D. Otter, T.A. Treibel, A. McKnight, D.M. Altmann, T. Brooks, M. Noursadeghi, R.J. Boyton, A. Semper, and J.C. Moon, Antibody response to first BNT162b2 dose in previously SARS-CoV-2-infected individuals. Lancet 397 (2021) 1057-1058.

[38] F. Krammer, K. Srivastava, H. Alshammary, A.A. Amoako, M.H. Awawda, K.F. Beach, M.C. Bermudez-Gonzalez, D.A. Bielak, J.M. Carreno, R.L. Chernet, L.Q. Eaker, E.D. Ferreri, D.L. Floda, C.R. Gleason, J.Z. Hamburger, K. Jiang, G. Kleiner, D. Jurczyszak, J.C. Matthews, W.A. Mendez, I. Nabeel, L.C.F. Mulder, A.J. Raskin, K.T. Russo, A.T. Salimbangon, M. Saksena, A.S. Shin, G. Singh, L.A. Sominsky, D. Stadlbauer, A. Wajnberg, and V. Simon, Antibody Responses in Seropositive Persons after a Single Dose of SARS-CoV-2 mRNA Vaccine. The New England journal of medicine 384 (2021) 1372-1374. 